\title{
INDIKATOR MAKROEKONOMI DAN PEMBANGUNAN KOTA BANDUNG
}

\author{
Teguh Santoso, Bayu Kharisma \\ Departemen Ilmu Ekonomi, Universitas Padjadjaran \\ Jl. Dipati Ukur No. 35 Bandung, 40132, Indonesia \\ Korespondensi Email : bayu.kharisma@unpad.ac.id
}

\begin{abstract}
ABSTRAK
Tingginya laju inflasi berpotensi meningkatkan angka kemiskinan karena dapat menurunkan daya beli masyarakat, dimana jika inflasi naik dengan signifikan maka dapat menggeser masyarakat yang terkategori tidak miskin, menjadi rentan miskin, hampir miskin bahkan miskin. Tujuan penelitian ini adalah menganalisa perkembangan indikator makroekonomi yaitu inflasi dan pertumbuhan ekonomi yang dikaitkan dengan tingkat kemiskinan di Kota Bandung. Metodologi yang digunakan dalam penelitian ini adalah analisis deskriptif dan Model ARMA (autoregressive moving average). Hasil penelitian menunjukkan bahwa tingginya inflasi di Kota Bandung dibanding inflasi nasional dan Jawa Barat membawa beban tersendiri bagi perekonomian masyarakat, dimana daya beli akan menurun ketika inflasi naik secara signifikan dan akan berdampak pada kesejahteraan masyarakat. Inflasi di Kota Bandung seringkali disebabkan harga komoditas pangan (volatile food inflation). Selain itu, tingginya pertumbuhan ekonomi di Kota bandung tidak berbanding lurus dengan penurunan tingkat kemiskinan. Hal ini menunjukkan bahwa kualitas pertumbuhan ekonomi di Kota Bandung ada permasalahan yang perlu diperhatikan. Oleh karena itu, Pemerintah Daerah dalam upaya mendorong pertumbuhan ekonomi harus tetap memperioritaskan pengurangan kemiskinan dan juga ketimpangan.
\end{abstract}

Kata Kunci : inflasi, pertumbuhan ekonomi, kemiskinan, analisis deskriptif, Model ARMA, ketimpangan

\begin{abstract}
The high rate of inflation has the potential to increase poverty because it can reduce people's purchasing power, where if inflation rises significantly it can shift the people who are categorized as not poor, become vulnerable to poverty, almost poor and even poor. The aims of this study are to analyze the development of macroeconomic indicators, namely inflation and economic growth that are associated with poverty levels in the city of Bandung. The methodology used in this study is descriptive analysis and the ARMA (autoregressive moving average) model. The results showed that the high inflation in the city of Bandung compared to national and West Java inflation carries its own burden for the economy of the community, where purchasing power will decrease when inflation rises significantly and will have an impact on people's welfare. Inflation in the city of Bandung is often due to the price of food commodities (volatile food inflation). In addition, the high economic growth in the city of Bandung is not directly proportional to the decline in poverty levels. This shows that the quality of economic growth in the city of Bandung has problems that need attention. Therefore, local government in their efforts to encourage economic growth must prioritize poverty reduction and inequality.
\end{abstract}

Keywords: inflation, economic growth, poverty, descriptive analysis, ARMA model, inequality 


\section{PENDAHULUAN}

Kota Bandung merupakan salah satu kota dengan pertumbuhan ekonomi tertinggi di Jawa Barat. Pada tahun 2017, laju pertumbuhan ekonomi Kota Bandung mencapai $7.21 \%$, jauh lebih tinggi dibanding pertumbuhan ekonomi Jawa Barat sebesar $5.29 \%$ bahkan nasional sebesar $5.07 \%$ pada periode yang sama. Namun demikian, laju pertumbuhan ekonomi yang tinggi tersebut, diikuti dengan tingginya laju inflasi. Kota Bandung menjadi Kota dengan Kontribusi tertinggi ketiga pada pembentukan inflasi Jawa Barat setelah Kota Bogor dan Kota Bekasi.

\section{Gambar 1: Inflasi di 7 Kota Jawa Barat}

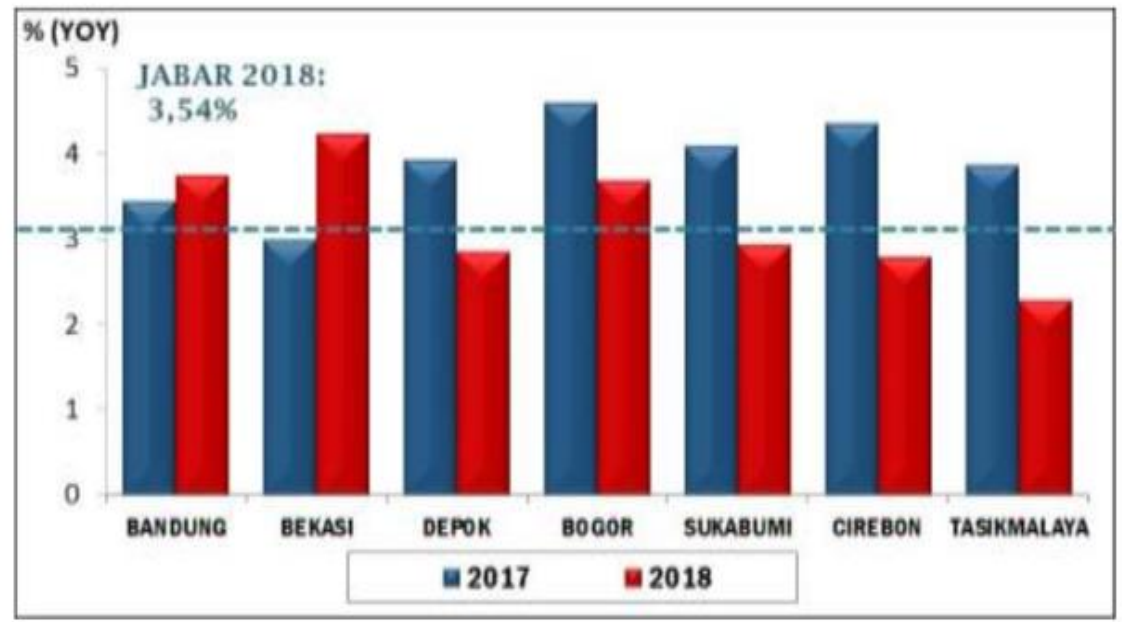

Sumber: Kajian Ekonomi dan Keuangan Regional, Bank Indonesia 2019.

Dengan pertumbuhan ekonomi yang tinggi dan menjadi Kota destinasi wisata, tentu berpotensi mendorong laju inflasi dari sisi permintaan di Kota Bandung. Selain itu, gejolak harga komoditas yang menyebabkan inflasi bahan makanan (volatile food inflation) yang cenderung fluktuatif serta kebijakan harga seperti harga $\mathrm{BBM}$ dan tarif transportasi turut mendorong laju inflasi. Relatif 
tingginya laju inflasi, akan berdampak pada penurunan daya beli masyarakat berpotensi meningkatkan jumlah penduduk miskin.

Kota Bandung sebagai salah satu kota di Indonesia dengan jumlah penduduk yang besar juga memiliki jumlah penduduk miskin (penduduk yang berada dibawah Garis Kemiskinan) yang cukup tinggi. Jumlah penduduk miskin di Kota Bandung pada tahun 2017 adalah sebanyak 103.980 orang atau sebesar $4,17 \%$ dari penduduk Kota Bandung. Jumlah ini mengalami penurunan jika dibandingkan dengan tahun sebelumnya, yaitu 107.580 orang. Sementara itu, dibandingkan dengan kota-kota lain di Jawa Barat, jumlah penduduk miskin Kota Bandung berada pada posisi kedua terbanyak setelah Kota Bekasi, dimana yang menempati posisi pertama dengan jumlah penduduk miskin terbanyak adalah Kota Bekasi yaitu sebanyak 136.100 jiwa dengan garis kemiskinan Kota Bekasi (Rp/Kap/bulan) sebesar Rp.544.534. Selanjutnya, kota dengan jumlah penduduk miskinnya yang paling sedikit adalah Kota Banjar yaitu sebanyak 12.870 jiwa dengan garis kemiskinan Kota Banjar (Rp/Kap/bulan) sebesar Rp.305.603. 
Gambar 2. Jumlah Penduduk Miskin di Kabupaten dan Kota di Jawa Barat Tahun 2017 Dalam (dalam 000)

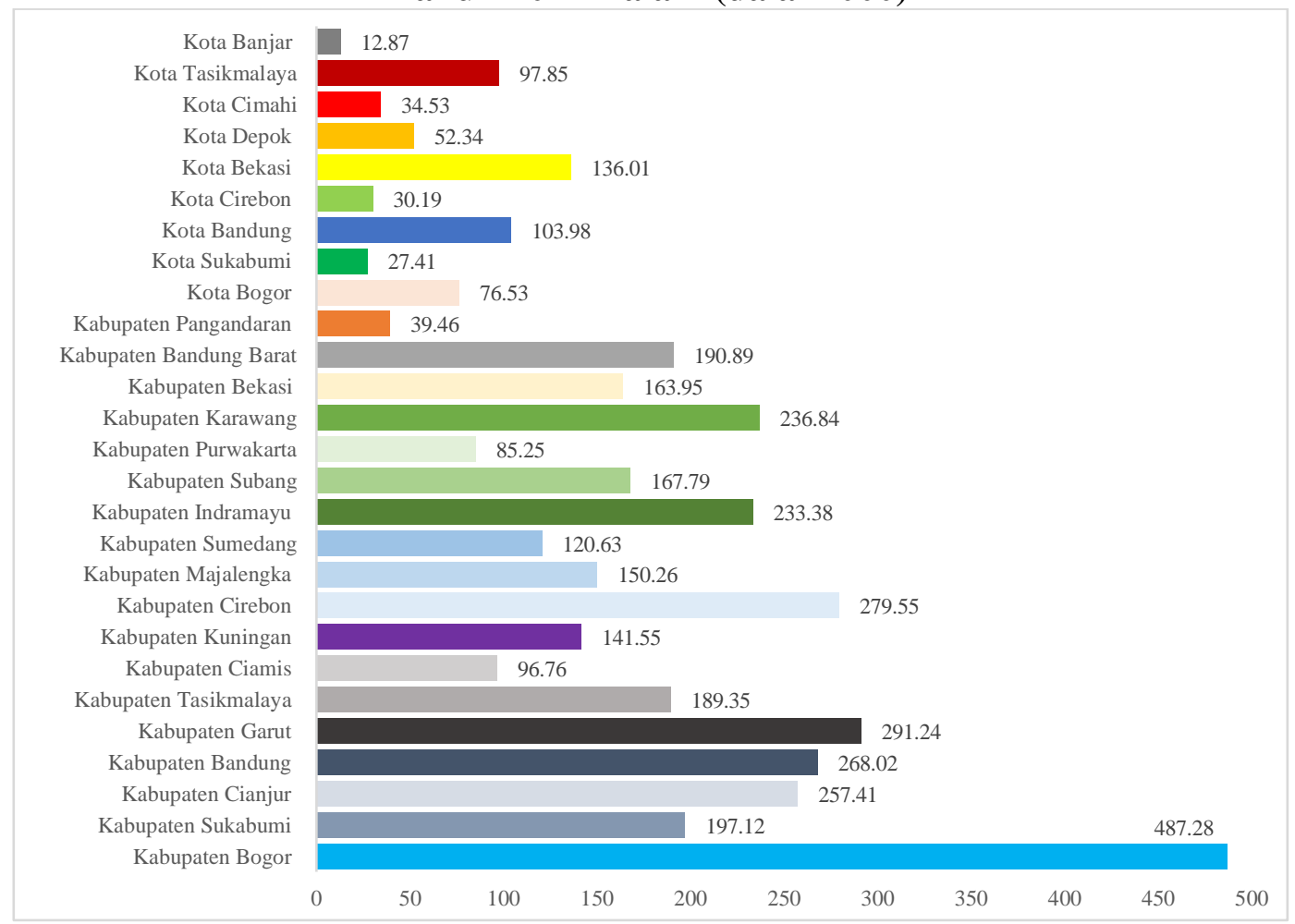

Sumber : BPS Provinsi Jawa Barat 2018, diolah

Dengan demikian, tingginya laju inflasi berpotensi dapat meningkatkan angka kemiskinan karena semakin menurunkan daya beli masyarakat. Jika inflasi naik dengan signifikan, maka dapat menggeser masyarakat yang terkategori tidak miskin, menjadi rentan miskin, hampir miskin bahkan miskin. Tingkat kemiskinan juga erat dengan kondisi struktur ekonomi. Oleh karenanya, diperlukan sebuah analisis deskriptif terhadap perkembangan indikator makroekonomi seperti inflasi dan pertumbuhan ekonomi, yang dikaitkan dengan indikator pembangunan, utamanya kemiskinan. 


\section{METODE PENELITIAN}

Metode yang digunakan dalam penelitian ini adalah analisis deskriptif dan Model ARMA (autoregressive moving average). Pada penelitian ini digunakan data deret waktu per tahun untuk menganalisa inflasi, pertumbuhan ekonomi dan juga kemiskinan. Data ini diperoleh dengan mengakses website resmi bank Indonesia, BPS Provinsi Jawa Barat dan Kota Bandung. Selain itu, penelitian ini dilakukan dengan menggunakan studi literatur yang diperoleh dari buku-buku maupun media lainnya untuk mendapatkan informasi untuk mendukung penulisan penelitian ini.

\section{HASIL DAN PEMBAHASAN}

Analisis perkembangan indikator makro kuartal I 2019 akan dilakukan terhadap perkembangan variabel inflasi dan pertumbuhan ekonomi. Analisis dilakukan berdasarkan data terbaru, dimana inflasi merupakan data inflasi bulanan yang memiliki rentang data dari tahun 2016.1 - 2019.3. Sementara itu, data pertumbuhan ekonomi diperoleh dari data Produk Domestik Regional Bruto (PDRB) harga konstan 2010, triwulanan dengan rentang data 2011-2017. Data PDRB terbaru yang tersedia pada BPS Bandung adalah data tahun 2017. Dengan demikian, belum bisa dilakukan analisis pertumbuhan ekonomi untuk data terbaru 2018.

Perkembangan dan proyeksi inflasi secara rata-rata, laju inflasi, year-on-year $(y-o-y)$ pada tahun 2018 lebih tinggi dibanding tahun 2017 dan 2016. Lebih dari itu, pada tahun 2018 laju inflasi Kota Bandung bahkan lebih tinggi dibanding laju inflasi Jawa Barat dan Nasional. Namun demikian, laju inflasi mulai menurun pada akhir 2018 - awal tahun 2019 (Januari-Maret), trend yang sama juga terjadi pada 
laju Inflasi nasional dan Jawa Barat. Meski demikian, pada awal 2019, secara ratarata inflasi (y-o-y) Kota Bandung masih sedikit lebih tinggi dibanding inflasi nasional dan Jawa Barat, dimana laju rata-rata laju inflasi Kota Bandung, Jawa Barat dan Nasional masing-masing sebesar 2,73\%, 2,69\% dan 2,72\%. Dapat diartikan bahwa laju inflasi awal 2019 lebih terkenali jika dibandingkan dengan dengan periode yang sama tahun 2016-2018.

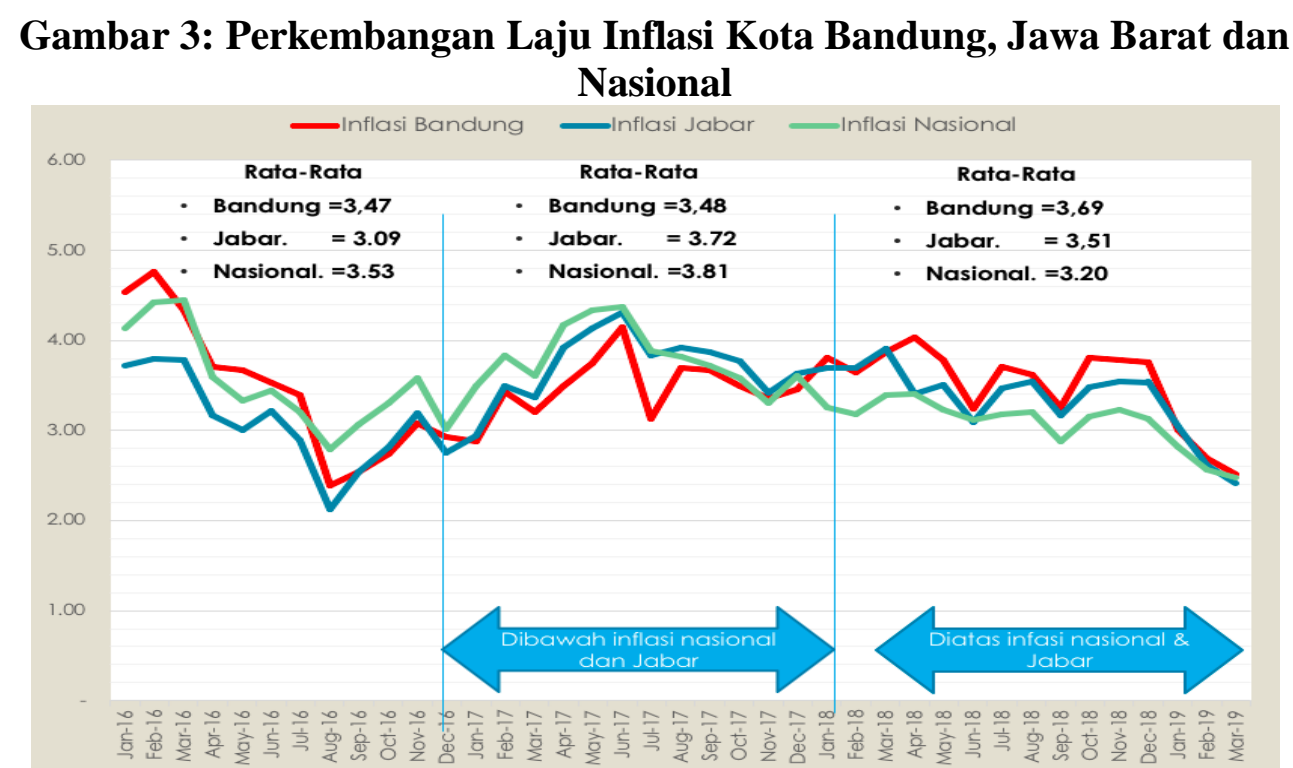

Sumber: Badan Pusat Statistik Kota Bandung, 2019, diolah.

Apabila dibandingkan laju inflasi 2017 dan 2018, terdapat perbedaan yang cukup mendasar. Pada tahun 2017, laju inflasi Kota Bandung secara umum selalu berada dibawah laju inflasi nasional dan Jawa Barat. Sementara kondisi sebaliknya terjadi pada 2018. Hal tersebut secara implisit mengindikasikan bahwa laju inflasi di Kota Bandung tahun 2017 lebih terkendali dibanding tahun 2018. Dengan demikian, ada hal penting yang membuat laju inflasi tahunan pada tahun 2017 lebih rendah dibanding 2018. Hal tersebut seyogyanya dapat menjadi perhatian bagi Tim 
Pengendalian Inflasi Daerah (TPID) Kota Bandung untuk dapat mengendalikan laju inflasi sebagaimana dapat dilakukan pada tahun 2017. Jika dilihat dari inflasi berdasarkan kategori pengeluaran, inflasi bahan makanan yang patut diduga menjadi penggerak tinggi rendahnya laju inflasi di Kota Bandung.

Gambar 4: Laju Inflasi Berdasarkan Kelompok Pengeluaran

PENDIDIIAN_REKREAS

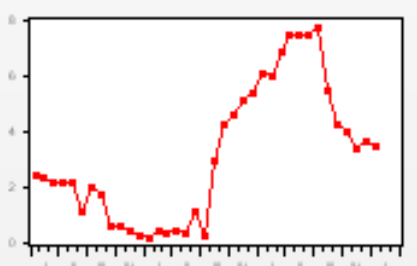

PERU MAHAN_AIR_LISTRIK_BB II

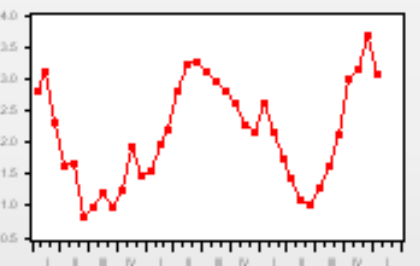

MAKANAN_JADI

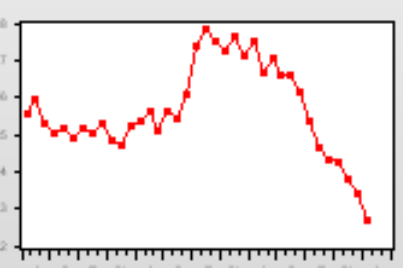

IESEHATAN

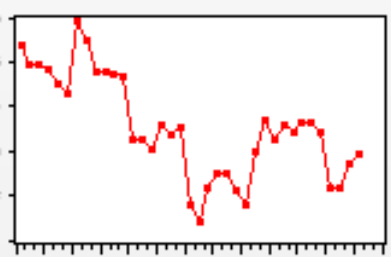

SANDANG

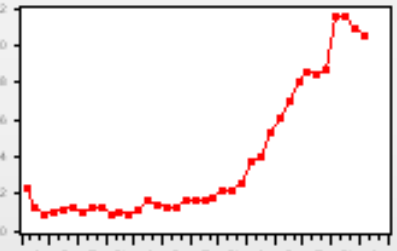

TRANSPORTASI

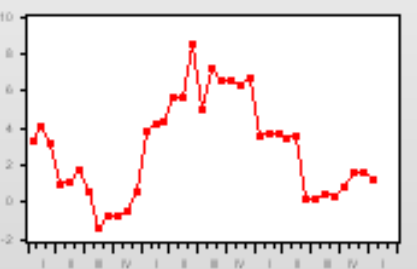

Sumber: Badan Pusat Statistik Kota Bandung, 2019, diolah.

Gambar 4 menunjukkan perkembangan laju inflasi (y-o-y) berdasarkan kelompok pengeluaran. Pada tahun 2017, inflasi kelompok bahan makanan menjadi satu-satunya kelompok yang menunjukkan trend penurunan laju inflasi sepanjang tahun. Kelompo kesehatan juga menunjukkan trend yang sama, namun menunjukkan peningkatan sejak kuartal III-IV 2017. Sementara kelompok lain, selalu menunjukkan kenaikan sepanjang 2017. Trend penurunan laju inflasi kelompok bahan makanan di Kota Bandung, patut diduga menjadi faktor relatif 
terkendalinya inflasi Kota Bandung, yang lebih rendah dibanding Nasional dan Jawa Barat pada tahun 2017. Kondisi sebaliknya terjadi pada tahun 2017, dimana laju inflasi kelompok bahan makanan menunjukkan trend peningkatan yang juga patut diduga mendorong tingginya laju inflasi Kota Bandung melebihi lajun inflasi nasional dan Jawa Barat.

Kelompok bahan makana memang menjadi kontributor terbesar pembentukan inflasi, bagitupun juga yang terjadi di Kota Bandung. Pada Januari 2019, kelompok bahan makanan menyumbang 0.16 pada pembentukan inflasi Kota Bandung dan merupakan yang terbesar dibanding kelompok yang lain. Dengan demikian, menjaga laju inflasi kelompok bahan makanan, yang terkategori volatile food inflation dapat menjadi faktor dominan dalam pengendalian inflasi di Kota Bandung.

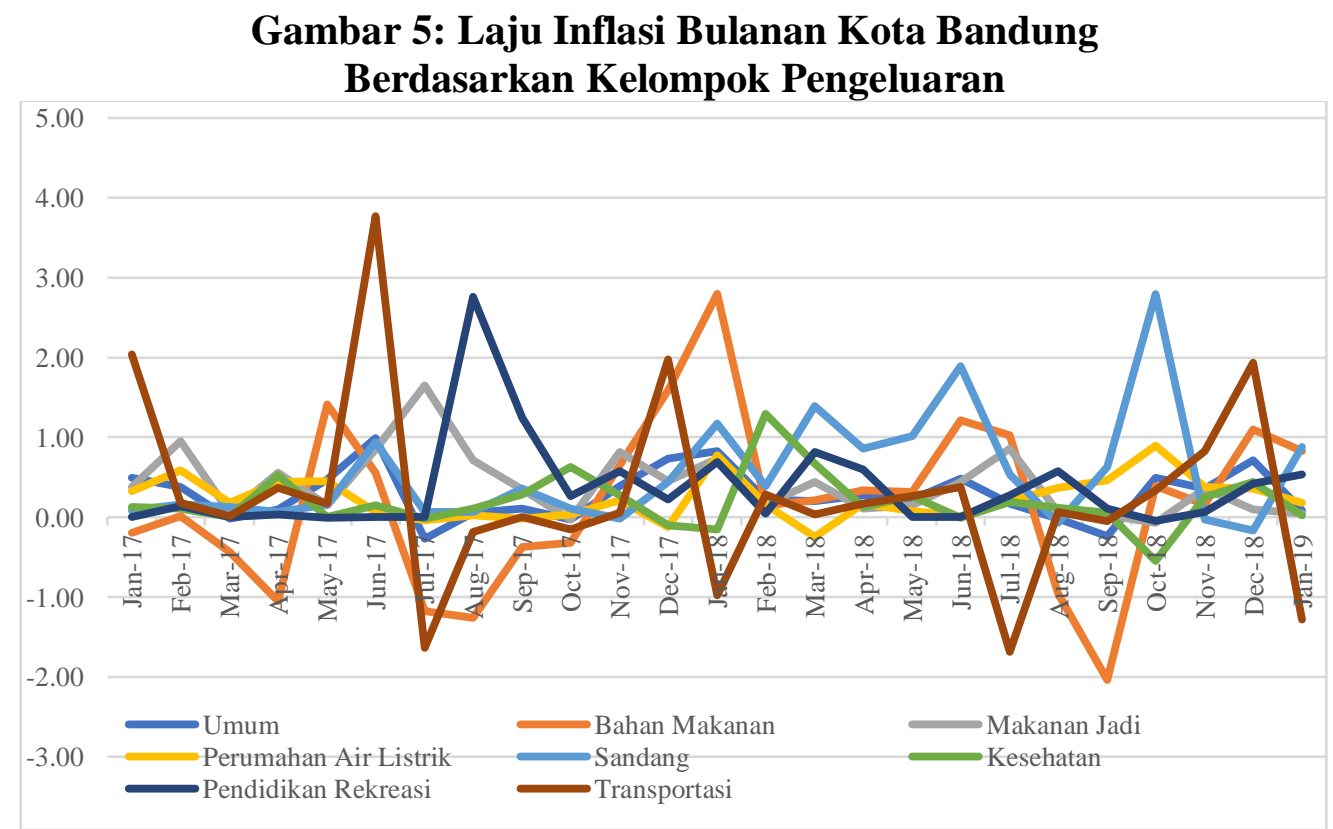

Sumber: Badan Pusat Statistik Kota Bandung. 
Jika dilihat laju inflasi bulanan (m-o-m), inflasi kelompok bahan makanan dan transportasi cenderung menunjukkan peningkatan sebelum, memasuki pada saat bulan Ramadhan dan Idul Fitri yakni pada periode April-Mei-Juni pada 2017 dan 2018. Demikian juga menjelang periode akhir tahun dimana terdapat momen hari raya Natal dan Tahun Baru, inflasi kelompok bahan makanan juga menunjukkan peningkatan (m-o-m). Pola trend yang sama juga terjadi pada kelompok Transportasi, Komunikasi dan Jasa Keuangan dimana inflasi kelompok tersebut juga menunjukkan peningkatan yang signifikan pada periode tersebut. Hal tersebut menunjukkan bahwa pengendalian inflasi kelompok bahan makanan dan transportasi perlu lebih difokuskan pada pertengahan tahun pada saat menjelang dan memasuki Ramadhan dan Idul Fitri, serta pada saat akhir tahun, namun tidak mengesampingkan pengendalian inflasi pada waktu diluar periode tersebut.

Proyeksi inflasi (Y-O-Y) proyeksi inflasi dilakukan dengan metode autoregressive (AR), dimana inflasi pada periode proyeksi mencerminkan potret kondisi inflasi periode sebelumnya. Dalam model AR, ditambahkan variabel kualitatif, yakni dummy periode Ramdhan-Idul Fitri dan Periode Libur Natal dan Tahun Baru, serta interaksi variabel dummy dengan trend pergerakan data. Hasil model Autoregressive disajikan dalam Tabel 1 berikut. 
Tabel 1: Estimasi Inflasi Model Autoregressive

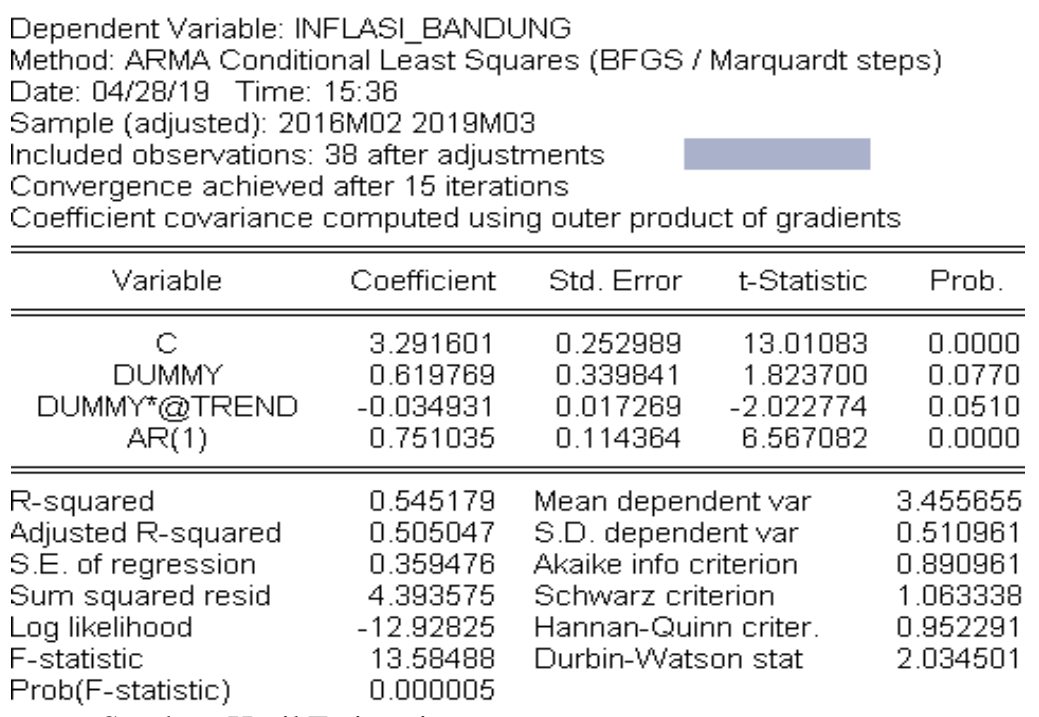

Sumber: Hasil Estimasi

Hasil estimasi menunjukkan bahwa nilai inflasi sangat dipengaruhi oleh pergerakan data periode sebelumnya (1 bulan sebelumnya) dengan tingkat signifikansi $1 \%$. Variabel dummy juga signifikan pada tingkat signifikansi $10 \%$. Artinya momen Ramdhan-Idul Fitri dan Periode Libur Natal dan Tahun Baru berdampak signifikan terhadap kenaikan laju inflasi pada periode tersebut. Variabel interaksi variabel dummy dan trend data menunjukkan pengaruh negatif dan signifikan. Artinya, momen Ramdhan-Idul Fitri dan Periode Libur Natal dan Tahun Baru berdampak signifikan terhadap kenaikan laju inflasi, namun nilai prediksinya akan lebih rendah dibanding dengan periode observasi. Hasil estimasi tersebut digunakan sebagai dasar proyeksi, sebagaimana hasil yang disajikan pada gambar 6 berikut. 


\section{Gambar 6: Proyeksi Inflasi Kota Bandung (y-0-y)}

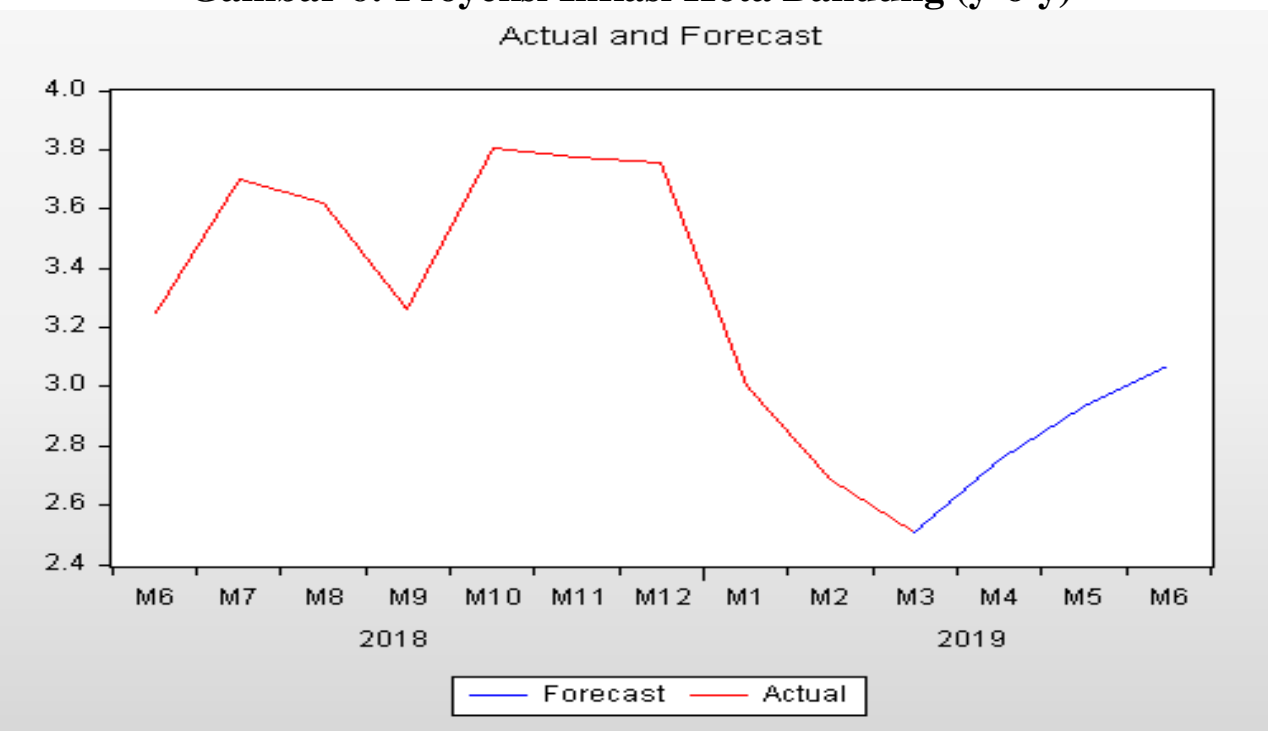

Sumber: Hasil estimasi penulis

Berdasarkan hasil estimasi inflasi model AR, diketahui bahwa periode April, Mei, Juni, inflasi Kota Bandung (y-o-y) diprediksikan berkisar antara 2,75\% 3,01\%. Diprediksikan meningkat dibanding periode Januari-Maret. Namun peningkatan tersebut lebih kecil dibanding dengan laju inflasi pada periode yang sama tahun 2017 dan 2018. Prediksi kenaikan inflasi tersebut dinilai wajar mengingat kenaikan inflasi mengikuti pola seasonal, Ramadhan dan Idul Fitri

Laju pertumbuhan ekonomi Kota Bandung (LPE) memiliki data yang relatif kurang terkini jika dibandingkan dengan indikator inflasi. Data terbaru yang ada adalah laju pertumbuhan ekonomi tahun 2017. LPE Kota Bandung Tahun 2017 sebesar 7.21\%, turun cukup signifikan jika dibanding dengan LPE 2016. Selain itu, capaian LPE 2017 juga merupakan yang terendah sejak tahun 2011. Penurunan kondisi ekonomi global patut diduga menjadi salah satu faktor penyebab relatif 
rendahnya LPE Kota Bandung, melalui jalur penurunan ekspor produk industri pengolahan. Berdasarkan data Kota Bandung Dalam Angka (2018), aktivitas industri pengolahan di Kota Bandung banyak didominasi oleh aktivitas industri tekstil dan pakaian jadi. Hal tersebut terlihat dari jumlah perusahaan yang beroperasi pada kedua sub-sektor tersebut sebanyak 246 perusahaan (menengah besar) atau $48 \%$ dari total perusahaan menengah besar yang ada di Kota Bandung. Dengan pelemahan kondisi ekonomi global, maka permintaan ekspor produk tekstil dan pakaian jadi juga menurun sehingga berdampak pada kinerja industri pengolahan dan akhirnya berkontribusi pada penurunan laju pertumbuhan ekonomi.

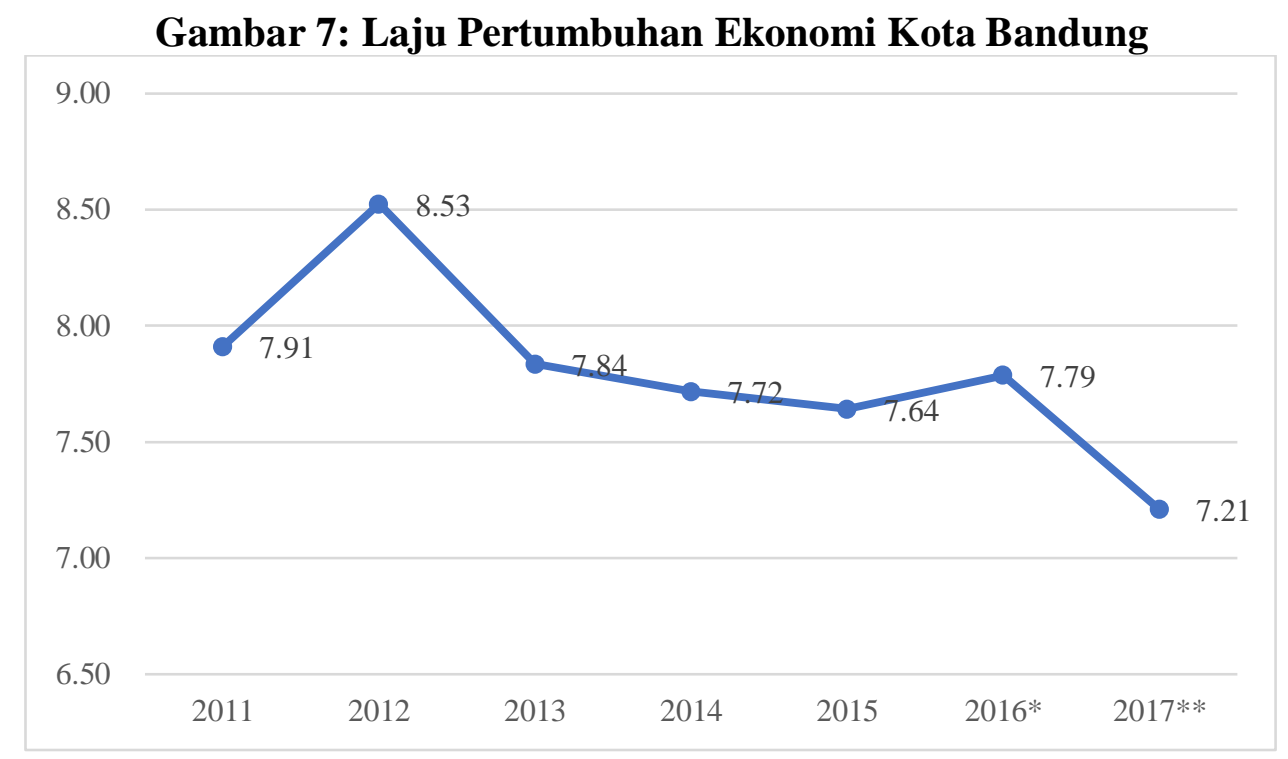

Sumber: Badan Pusat Statistik Kota Bandung, 2019, diolah

Dari sisi laju pertumbuhan sektoral, pertumbuhan yang tinggi banyak didominasi oleh sektor tersier seperti sektor transportasi dan pergudangan, sektor telekonomunikasi, penyediaana akomodasi makan minum dan sektor jasa pendidikan dan kesehatan. Sementara itu, sektor primer dan sektor sekunder seperti pertanian, industri pengolahan dan perdagangan, masih menunujukkan kinerja 
pertumbuhan yang positif, namun tidak sepesat pertumbuhan ekonomi sektor tersier. Hal ini menunjukkan, dari sisi pertumbuhan sektoral, terdapat potensi pergeseran struktur ekonomi dari sektor primer-sekunder menuju sektor tersier. Kondisi tersebut juga dapat dilihat dari kontribusi sektoral terhadap PDRB.

\section{Gambar 8: Laju Pertumbuhan Ekonomi Sektoral, PDRB Harga Konstan} 2010

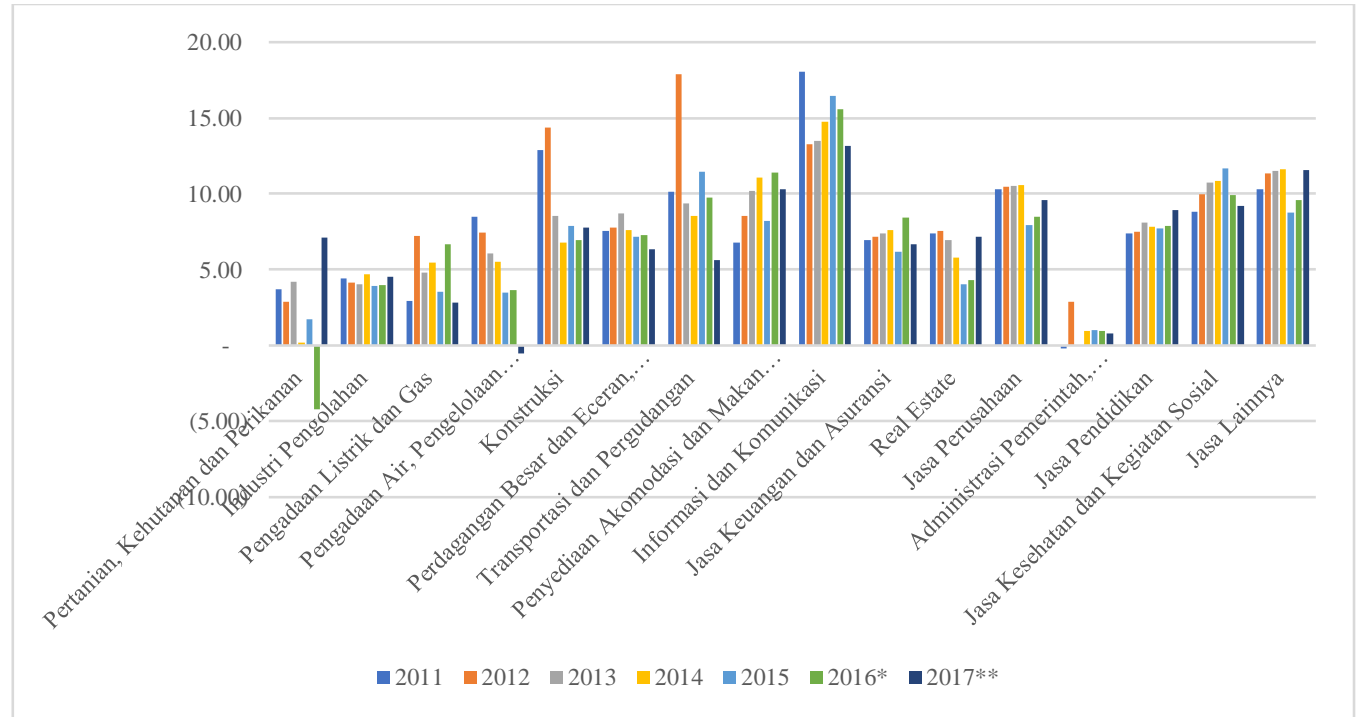

Sumber: Badan Pusat Statistik Kota Bandung, 2019 diolah

Gambar 8 menunjukkan kontribusi sektoral terhadap PDRB Kota Bandung tahun 2011-2017. Sektor Industri Pengolahan sebagai sektor dengan kontribusi terbesar kedua menunjukkan kontribusi yang terus menurun sejak tahun 2011. Sektor Perdagangan Besar dan Eceran, Reparasi Mobil dan Sepeda Motor sebagai sektor dengan kontribusi terbesar menunjukkan kontribusi yang relatif konstan sejak 2011, bahkan cenderung sedikit menurun sejak 2013-2017. Sektor dengan kontribusi yang terus menunjukkan peningkatan adalah sektor informasi dan komunikasi, seiring dengan perkembangan ekonomi digital dan sharing economy. Juga Hal ini menunjukkan adanya indikasi pergeseran struktur perekonomian. 


\section{Gambar 9: Kontribusi Sektoral Terhadap PDRB Harga Konstan 2010}

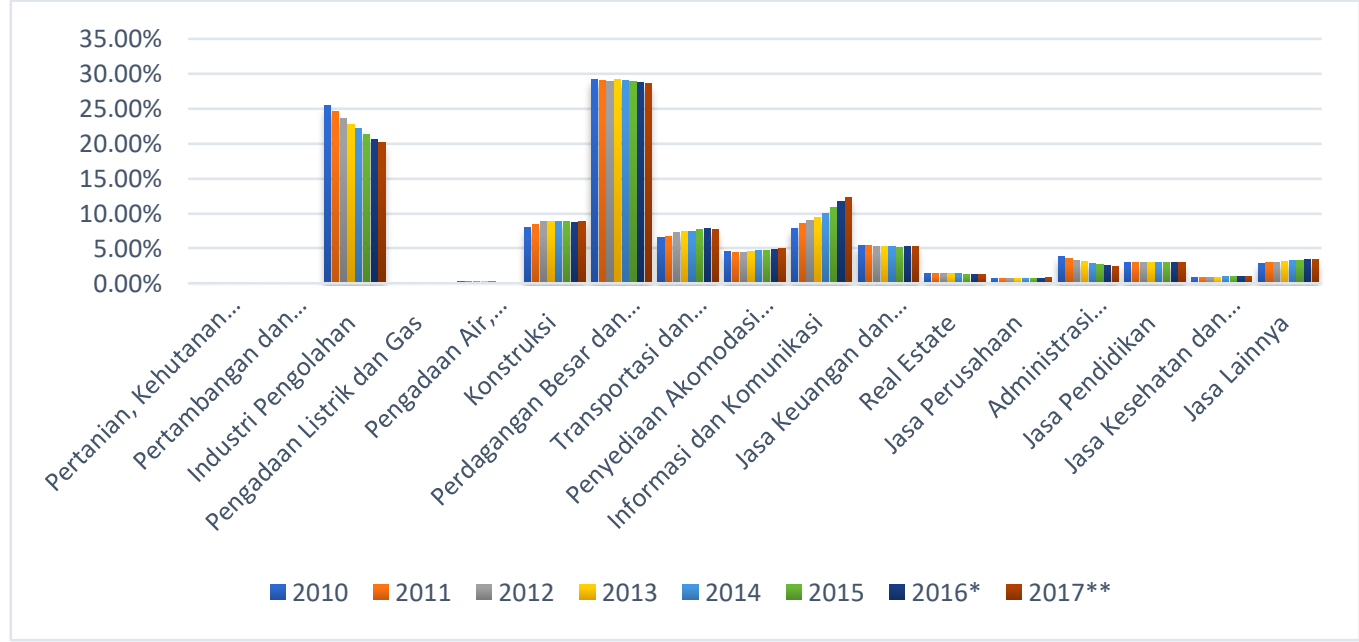

Sumber: Badan Pusat Statistik Kota Bandung, 2019 diolah

Jumlah penduduk miskin selama enam belas tahun terakhir cenderung fluktuatif, sedangkan dari sisi tren mengalami peningkatan (lihat Gambar 10). Pada periode tahun 2018, jumlah penduduk miskin di Kota Bandung sebesar 89.380 orang atau menurun 14,04 persen dibanding tahun 2017 yang mencapai 103.980 jiwa. Sementara itu, apabila ditinjau dari penurunan kemiskinan pada periode tahun 2013-2018, angka kemiskinan secara rata-rata mampu turun sebesar 24,06 persen per tahun. Penurunan jumlah orang miskin tersebut tidak lepas dari adanya pemberian bantuan pemerintah melalui Program Keluarga Harapan (PKH) dan pendampingan Tenaga Kerja Sosial Kecamatan (TKSK) yang telah berjalan baik serta tingginya kesadaran masyarakat Kota Bandung untuk saling membantu sehingga memberikan berkontribusi terhadap penurunan angka kemiskinan. 
Gambar 10. Jumlah Penduduk Miskin di Kota Bandung, 2002-2018 Dalam (dalam 000)

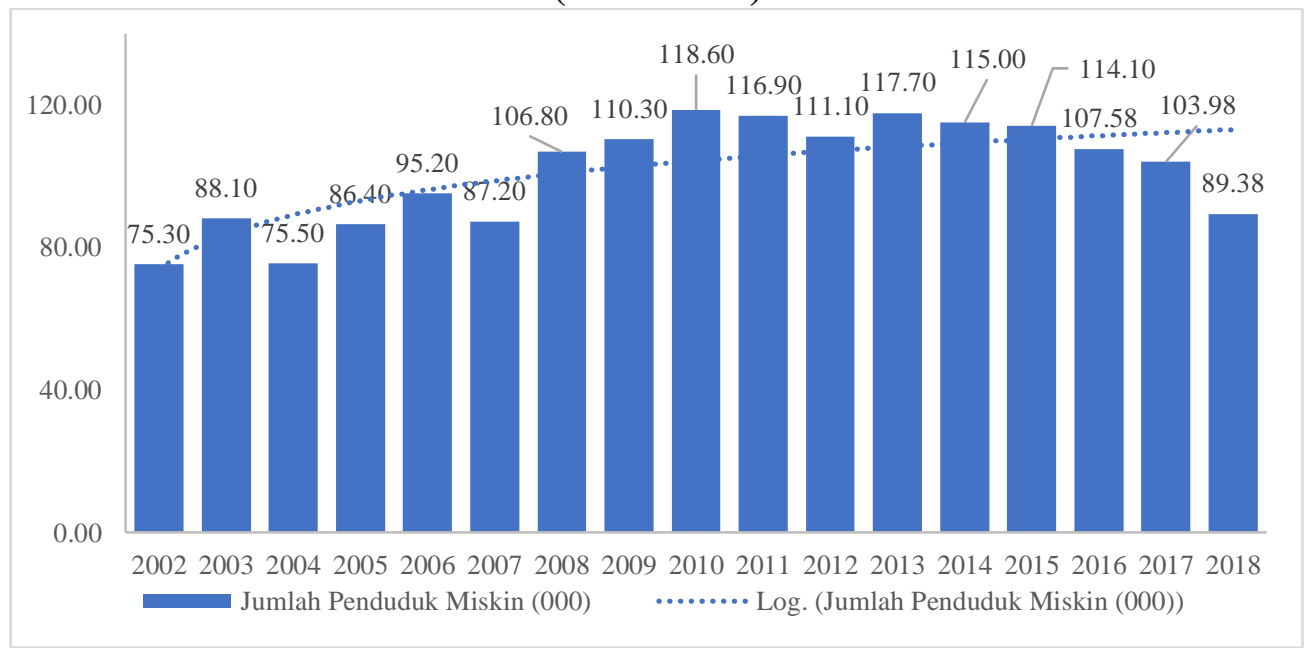

Sumber : BPS Provinsi Jawa Barat 2018, diolah

Sebenarnya berbicara tentang kemiskinan makro tak lepas dari besaran garis kemiskinan. Garis kemiskinan (Poverty Line) menunjukkan jumlah rupiah minimum yang dibutuhkan untuk memenuhi kebutuhan pokok minimum makanan setara dengan 2100 kilo kalori per kapita per hari dan kebutuhan pokok bukan makanan. Garis kemiskinanan di Kota Bandung selama periode 2010-2018 mempunyai pola semakin meningkat dengan rata-rata sebesar Rp. 358.527 (lihat Gambar 10). Pembentuk garis kemiskinan di Kota Bandung masih didominasi oleh kelompok pengeluaran bahan makanan, antara lain beras, bawang merah, bawang putih, daging ayam ras, cabe merah, bayam, jagung manis dan lainnya yang mencapai 3,76\% selama bulan November-Desember 2018 (BPS, 2018). Oleh karena itu, tidak dapat dipungkiri bahwa melakukan pengawasan atau mengawal stabilitas harga penyumbang garis kemiskinan akan membantu memperlambat laju pertumbuhan garis kemiskinan di Kota Bandung. 
Gambar 11. Garis Kemiskinan (Rp/Kapita/Bulan) Kota Bandung, 2010-2017 (Rupiah)

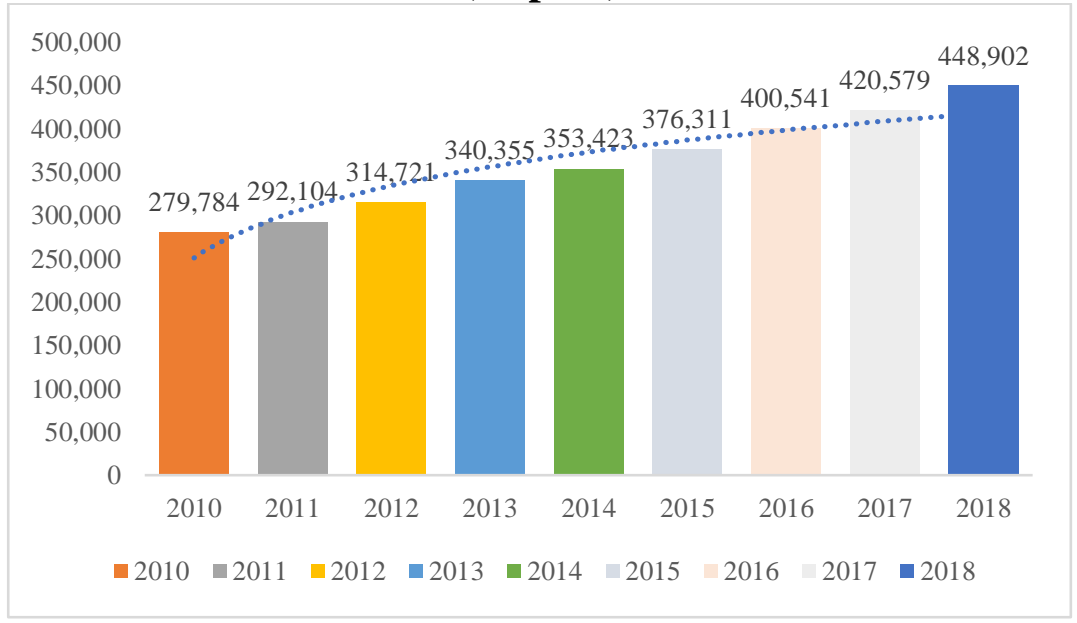

Sumber : BPS Provinsi Jawa Barat 2018, diolah

Profil kemiskinan akan lebih akurat bila ditinjau dari kualitas kemiskinan.

Indikator ini ditunjukkan melalui nilai Indeks Kedalaman Kemiskinan (P1) dan Indeks keparahan kemiskinan(P2). Indeks Kedalaman Kemiskinan (poverty gap index-P1) adalah ukuran rata-rata kesenjangan pengeluaran masing-masing penduduk miskin terhadap garis kemiskinan. Semakin tinggi nilai indeks, semakin jauh rata-rata pengeluaran penduduk dari garis kemiskinan. Indeks Keparahan Kemiskinan (poverty severity index-P2) adalah ukuran yang memberikan gambaran mengenai penyebaran pengeluaran di antara penduduk miskin. Semakin tinggi nilai indeks, semakin tinggi ketimpangan pengeluaran di antara penduduk miskin. 


\section{Gambar 12: Indeks Kedalaman Kemiskinan dan Indeks Keparahan} Kemiskinan Kota Bandung, 2010-2018

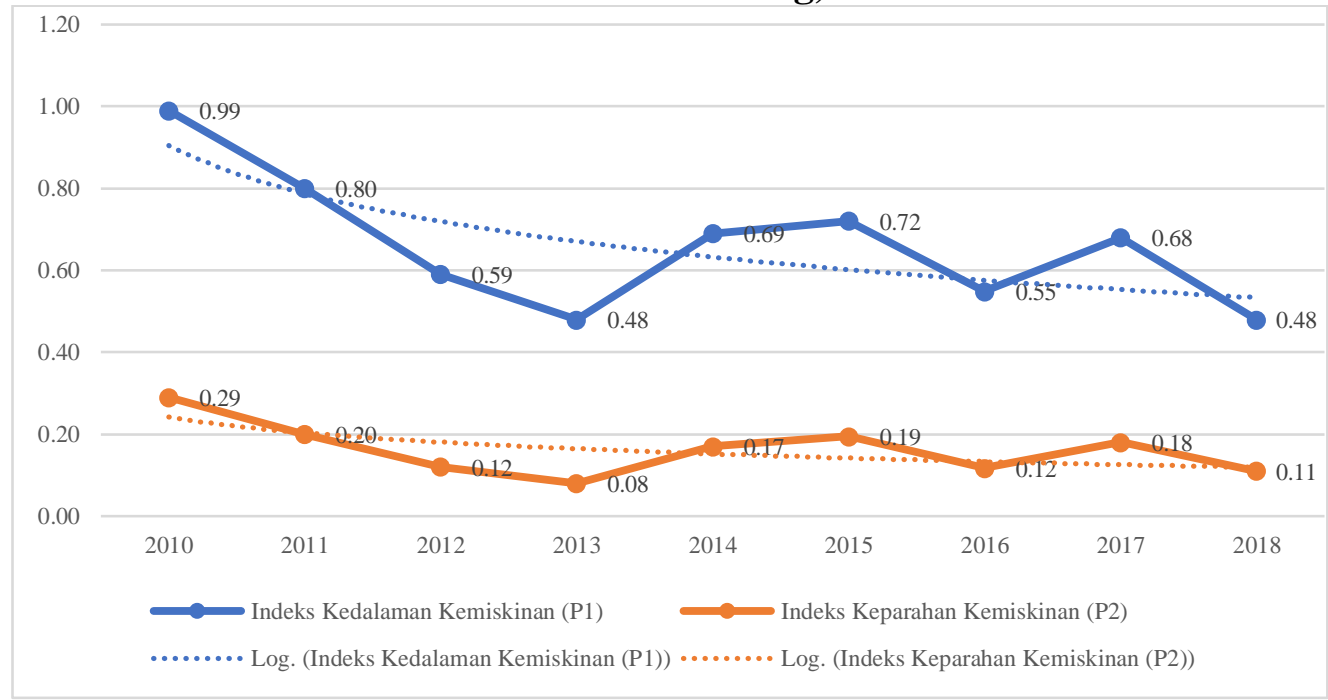

Sumber : BPS Provinsi Jawa Barat 2018, diolah

Gambar 12 menunjukkan bahwa pergerakan P1 dan P2 di kota Bandung antar periode memiliki pola tidak jauh berbeda dan memiliki trend yang cenderung menurun. Pada tahun 2018, Indeks Kedalaman Kemiskinan di Kota Bandung sebesar 0,48 atau lebih rendah 0,20 poin dibandingkan tahun 2017 yang mencapai 0,68. Artinya, semakin dekat rata-rata pengeluaran penduduk dari garis kemiskinan yang terjadi di Kota Bandung. Hal ini tidak lepas antara lain dari bantuan sosial dalam Program Keluarga Harapan (PKH) dan pendampingan Tenaga Kerja Sosial Kecamatan (TKSK) yang telah berjalan baik dalam memperbaiki indeks kedalaman kemiskinan (poverty gap). Begitu pula halnya dengan kondisi Indeks Keparahan Kemiskinan yang mengalami penurunan dari 0,18 pada tahun 2017 menjadi 0,11 di tahun 2018. Hal ini menunjukkan bahwa ketimpangan pengeluaran diantara penduduk miskin cenderung semakin menyempit setiap tahun. 
Gambar 13. Rasio Gini Kota Bandung, 2010-2018

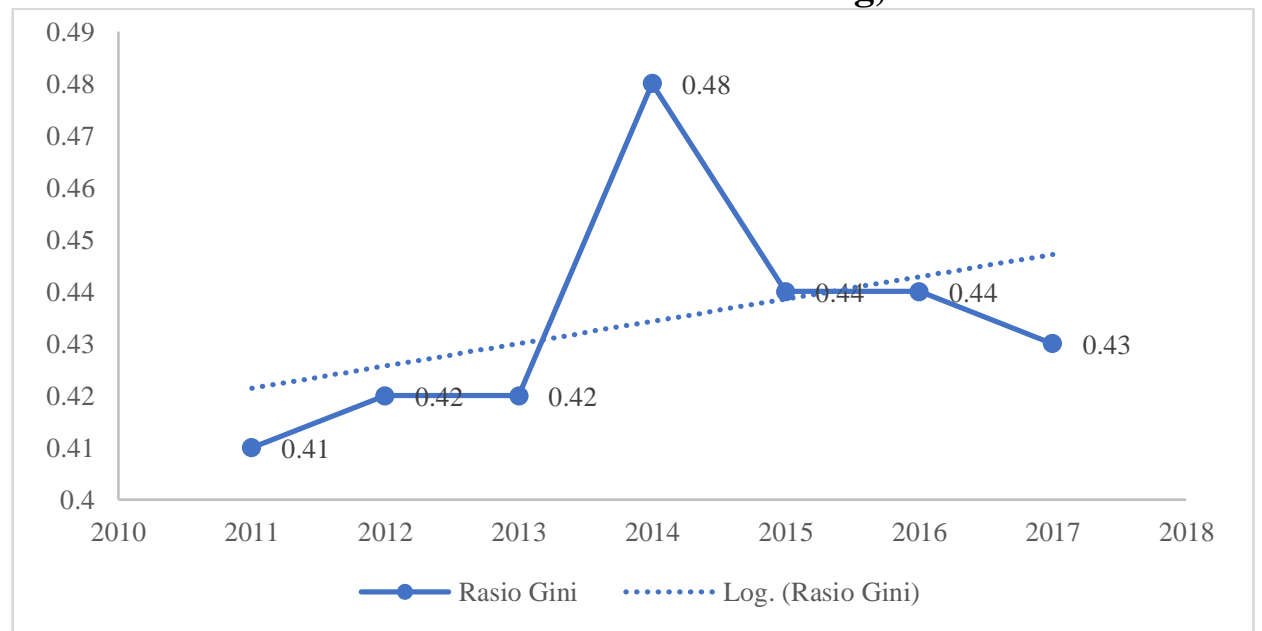

Sumber : BPS Provinsi Jawa Barat 2018, diolah

Menurunnya tingkat kemiskinan di Kota Bandung masih dibayang-bayangi kemungkinan meningkatnya indeks keparahan dan kedalaman kemiskinan, juga diiringi dengan kecenderungan ketimpangan yang semakin tinggi. Pada tahun 2016, koefisien Gini di Kota Bandung mencapai 0,44, namun pada tahun 2017 menurun menjadi 0,43. Meskipun koefisien Gini tahun 2017 lebih rendah daripada tahun 2016, namun dilihat dari kecenderungannya (trend logarithmic) menunjukkan bahwa rasio gini selama periode pengamatan (2011-2017) semakin meningkat (lihat Gambar 13 diatas). 
Gambar 14. Kemiskinan dan Laju Inflasi Kota Bandung 2013 - 2017 (Persen)

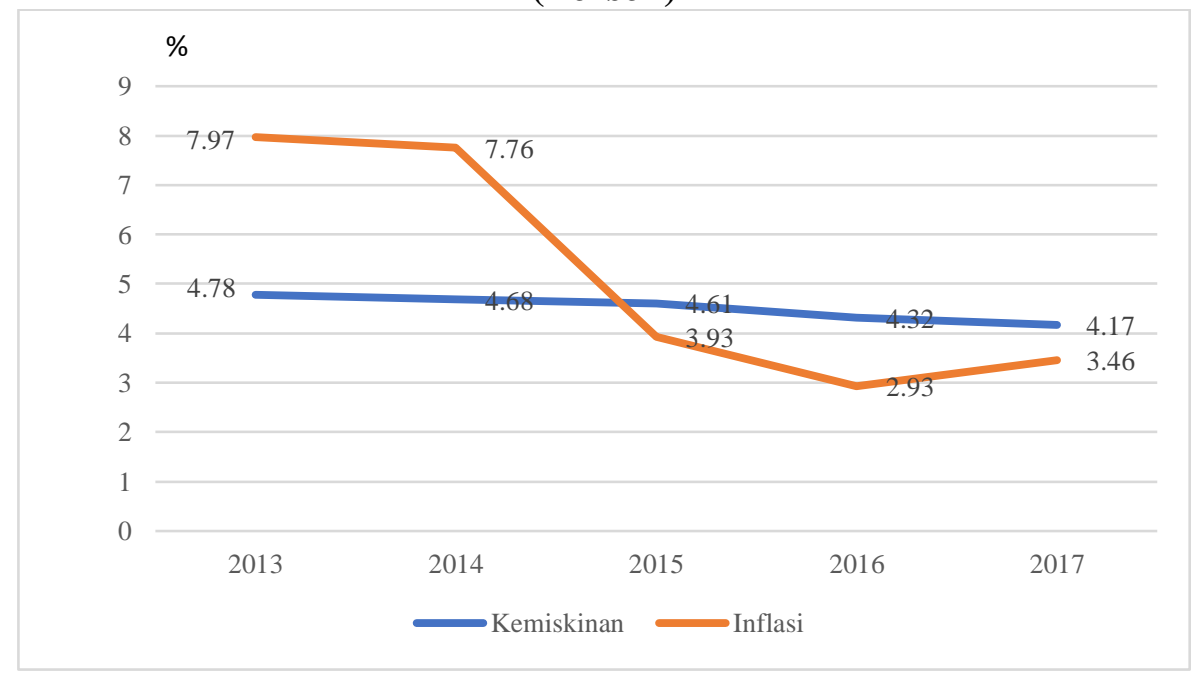

Sumber : BPS Provinsi Jawa Barat 2018, diolah

Gambar 14 diatas memperlihatkan perkembangan persentase penduduk kemiskinan dengan tingkat inflasi di Kota Bandung. Tingkat inflasi di Kota Banding pada periode tahun 2013-2016 cenderung menurun, namun pada tahun 2017 mengalami peningkatan sebesar 3,46\%. Kenaikan inflasi pada tahun 2017 disebabkan oleh peningkatan inflasi pada kelompok core disumbang oleh beberapa komoditas yang menjadi kebutuhan pada momen Idul Fitri dan fenomena mudik lebaran, termasuk emas perhiasan juga menjadi penyumbang inflasi pada kelompok ini serta dampak kenaikan tarif listrik golongan 900VA tahap III. Sementara itu, tingkat kemiskinan periode pengamatan (2013-2017) semakin menurun. Hasil analisis korelasi menunjukkan adanya hubungan positif yang sangat kuat antara persentase penduduk kemiskinan dengan tingkat inflasi di Kota Bandung sebesar 0,83 (lihat Tabel 2). Artinya, ada hubungan yang sangat kuat antara tingkat inflasi terhadap persentase penduduk kemiskinan di Kota Bandung. Dengan demikian, 
dapat disimpulkan bahwa tingkat inflasi berhubungan positif terhadap persentase penduduk kemiskinan di Kota Bandung,

Tabel 2. Korelasi antara Kemiskinan dan Laju Inflasi Kota Bandung , 2013 - 2017 (Persen)

\begin{tabular}{lcc}
\hline \hline & Kemiskinan & Inflasi \\
\hline \hline Kemiskinan & 1 & 0.8264 \\
Inflasi & 0.8264 & 1 \\
\hline \multicolumn{2}{c}{ Sumber : BPS Provinsi Jawa Barat 2018, diolah } &
\end{tabular}

Pertumbuhan ekonomi Kota Bandung tahun 2015 mencapai 7,63\% dan lebih tinggi dibandungkan beberapa kota di Jawa Barat, termasuk Provinsi Jawa Barat itu sendiri lihat Gambar 14 dibawah). Aktivitas ekonomi Kota Bandung, sebagian besar bersumber dari dari sektor perdagangan, hotel dan restoran yang memberikan, disusul oleh sektor industri pengolahan, sektor pengangkutan dan komunikasi dan sektor jasa-jasa. Selain itu, Bandung sebagai kota tujuan wisata dan pendidikan.

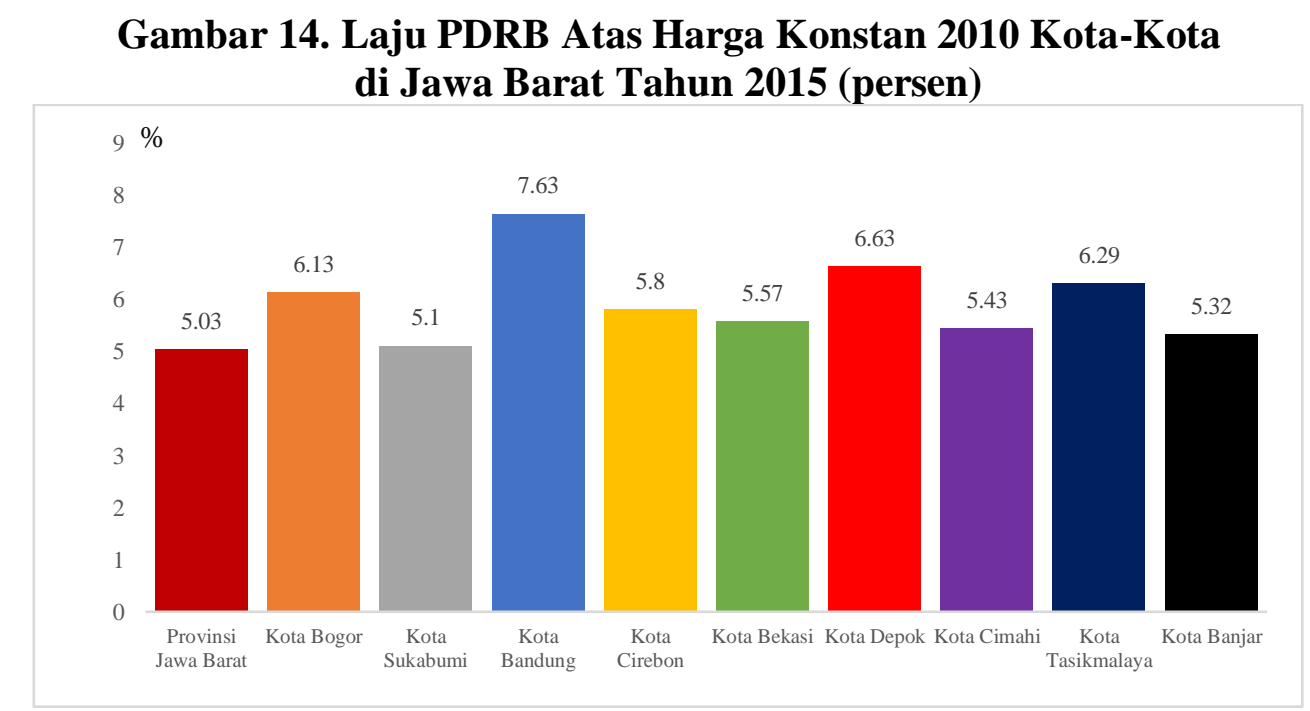

Sumber : BPS Provinsi Jawa Barat 2018, diolah 
Pertumbuhan ekonomi dan tingkat kemiskinan di kota Bandung pada periode pengamatan (2011-2017) semakin menurun. Sementara itu, dari hasil analisis korelasi, ada hubungan positif antara pertumbuhan ekonomi dan tingkat kemiskinan di Kota Bandung, namun hubungannya tidak kuat karena angka korelasinya sebesar 0,44 (lihat Tabel 3). Berdasarkan analisis korelasi dapat disimpulkan bahwa ada permasalahan dengan kualitas pertumbuhan ekonomi di Kota Bandung.

Gambar 15. LPE Kota Bandung dan Angka Kemiskinan, 2011 - 2017 (Persen)

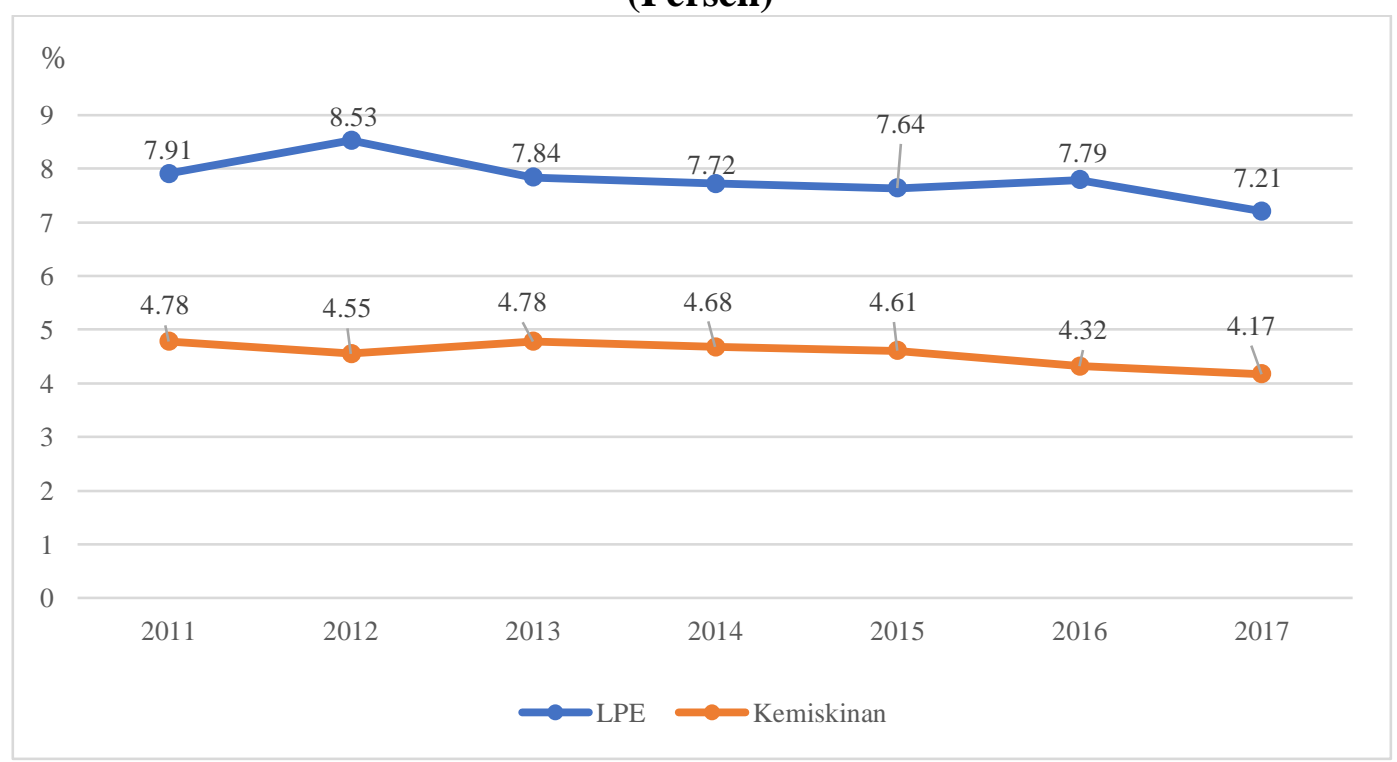

Sumber : BPS Provinsi Jawa Barat 2018, diolah

Tabel 3. Korelasi antara Laju Pertumbuhan Ekonomi (LPE) dan Tingkat Kemiskinan Kota Bandung, 2011 - 2017 (Persen)

\begin{tabular}{lcc}
\hline \hline & $\begin{array}{c}\text { Laju Pertumbuhan } \\
\text { Ekonomi (LPE) }\end{array}$ & Kemiskinan \\
\hline \hline $\begin{array}{l}\text { Laju Pertumbuhan } \\
\text { Ekonomi (LPE) }\end{array}$ & 1 & 0,44 \\
Kemiskinan & 0,44 & 1 \\
\hline
\end{tabular}

Sumber : BPS Provinsi Jawa Barat 2018, diolah 
Berdasarkan pertumbuhan ekonomi sektoral, terdapat korelasi negatif antara pertumbuhan sektoral dengan tingkat kemiskinan, kecuali sektor pertanian, kehutanan dan perikanan, pengadaan air, pengelolaan sampah, limbah dan daur ulang. konstruksi, perdagangan besar dan eceran, reparasi mobil dan sepeda motor, transportasi dan pergudangan, real estate, jasa perusahaan, jasa kesehatan dan kegiatan sosial dan jasa lainnya memiliki korelasi positif dengan tingkat kemiskinan dengan rata-rata sebesar 0,36. Hasil ini menguatkan bahwa pertumbuhan ekonomi sektoral di Kota Bandung masih belum mampu mendorong penurunan tingkat kemiskinan secara signifikan.

Tabel 4. Pertumbuhan Sektoral Kota Bandung dan Angka Kemiskinan, 2011 - 2017 (Persen)

\begin{tabular}{|c|c|c|c|c|c|c|c|c|c|}
\hline$\underset{\text { ri }}{\text { Katego }}$ & Keterangan & $\begin{array}{c}201 \\
1\end{array}$ & $\begin{array}{c}201 \\
2\end{array}$ & $\begin{array}{c}201 \\
3\end{array}$ & $\begin{array}{c}201 \\
4\end{array}$ & $\begin{array}{c}201 \\
5\end{array}$ & $\begin{array}{c}201 \\
6\end{array}$ & $\begin{array}{c}201 \\
7\end{array}$ & $\begin{array}{c}\text { Korelasi } \\
\text { dengan } \\
\text { Kemiskina } \\
\text { n } \\
\end{array}$ \\
\hline [1] & {$[2]$} & [3] & [4] & [5] & [6] & {$[7]$} & {$[8]$} & {$[9]$} & {$[10]$} \\
\hline A & $\begin{array}{l}\text { Pertanian, Kehutanan dan } \\
\text { Perikanan }\end{array}$ & 3,69 & 2,86 & 4,18 & 0,17 & 1,73 & $\overline{4}-\overline{22}$ & 7,14 & 0,02 \\
\hline B & Pertambangan dan Penggalian & - & - & - & - & - & - & - & - \\
\hline $\mathrm{C}$ & Industri Pengolahan & 4,41 & 4,12 & 4,06 & 4,71 & 3,94 & 4,01 & 4,53 & $-0,04$ \\
\hline $\mathrm{D}$ & Pengadaan Listrik dan Gas & 2,91 & 7,21 & 4,82 & 5,47 & 3,55 & 6,70 & 2,82 & $-0,04$ \\
\hline $\mathrm{E}$ & $\begin{array}{l}\text { Pengadaan Air, Pengelolaan } \\
\text { Sampah, Limbah dan Daur } \\
\text { Ulang }\end{array}$ & 8,51 & 7,44 & 6,10 & 5,52 & 3,51 & 3,67 & $0, \overline{53}$ & 0,82 \\
\hline $\mathrm{F}$ & Konstruksi & $\begin{array}{c}12,9 \\
1\end{array}$ & $\begin{array}{c}14,3 \\
7\end{array}$ & 8,54 & 6,80 & 7,86 & 6,93 & 7,76 & 0,32 \\
\hline G & $\begin{array}{l}\text { Perdagangan Besar dan Eceran, } \\
\text { Reparasi Mobil dan Sepeda } \\
\text { Motor }\end{array}$ & 7,57 & 7,75 & 8,71 & 7,62 & 7,17 & 7,26 & 6,37 & 0,79 \\
\hline $\mathrm{H}$ & Transportasi dan Pergudangan & $\begin{array}{c}10,1 \\
5\end{array}$ & $\begin{array}{c}17,9 \\
0\end{array}$ & 9,39 & 8,56 & $\begin{array}{c}11,4 \\
7\end{array}$ & 9,74 & 5,65 & 0,30 \\
\hline I & $\begin{array}{l}\text { Penyediaan Akomodasi dan } \\
\text { Makan Minum }\end{array}$ & 6,76 & 8,53 & $\begin{array}{c}10,1 \\
8\end{array}$ & $\begin{array}{c}11,0 \\
5\end{array}$ & 8,23 & $\begin{array}{c}11,4 \\
1\end{array}$ & $\begin{array}{c}10,3 \\
2\end{array}$ & $-0,47$ \\
\hline $\mathrm{J}$ & Informasi dan Komunikasi & $\begin{array}{c}18,0 \\
5\end{array}$ & $\begin{array}{c}13,2 \\
6\end{array}$ & $\begin{array}{c}13,4 \\
8\end{array}$ & $\begin{array}{c}14,7 \\
4\end{array}$ & $\begin{array}{c}16,4 \\
7\end{array}$ & $\begin{array}{c}15,5 \\
8\end{array}$ & $\begin{array}{c}13,1 \\
6\end{array}$ & 0,38 \\
\hline $\mathrm{K}$ & Jasa Keuangan dan Asuransi & 6,93 & 7,20 & 7,40 & 7,63 & 6,18 & 8,46 & 6,70 & $-0,12$ \\
\hline $\mathrm{L}$ & Real Estate & 7,42 & 7,57 & 6,95 & 5,77 & 4,06 & 4,32 & 7,18 & 0,16 \\
\hline $\mathrm{M}, \mathrm{N}$ & Jasa Perusahaan & $\begin{array}{c}10,3 \\
1\end{array}$ & $\begin{array}{c}10,4 \\
6\end{array}$ & $\begin{array}{c}10,5 \\
2\end{array}$ & $\begin{array}{c}10,5 \\
6\end{array}$ & 7,94 & 8,48 & 9,61 & 0,43 \\
\hline $\mathrm{O}$ & $\begin{array}{l}\text { Administrasi Pemerintah, } \\
\text { Pertahanan dan Jaminan Sosial } \\
\text { Wajib }\end{array}$ & $0,-$ & 2,88 & $\overline{-}, 02$ & 0,94 & 1,03 & 0,97 & 0,78 & $-0,32$ \\
\hline
\end{tabular}




\begin{tabular}{|c|c|c|c|c|c|c|c|c|c|}
\hline $\mathrm{P}$ & Jasa Pendidikan & 7,38 & 7,49 & 8,09 & 7,85 & 7,73 & 7,88 & 8,93 & $-0,67$ \\
\hline Q & $\begin{array}{l}\text { Jasa Kesehatan dan Kegiatan } \\
\text { Sosial }\end{array}$ & 8,82 & 9,98 & $\begin{array}{c}10,7 \\
2\end{array}$ & $\begin{array}{c}10,8 \\
7\end{array}$ & $\begin{array}{c}11,6 \\
5\end{array}$ & 9,94 & 9,18 & 0,31 \\
\hline $\begin{array}{l}\mathrm{R}, \mathrm{S}, \mathrm{T}, \\
\mathrm{U}\end{array}$ & Jasa Lainnya & $\begin{array}{c}10,2 \\
8\end{array}$ & $\begin{array}{c}11,3 \\
3\end{array}$ & $\begin{array}{c}11,4 \\
9\end{array}$ & $\begin{array}{c}11,6 \\
2\end{array}$ & 8,76 & 9,60 & $\begin{array}{c}11,5 \\
4\end{array}$ & 0,02 \\
\hline
\end{tabular}

Sumber : BPS Provinsi Jawa Barat 2018, diolah

Pertumbuhan ekonomi sektoral yang memiliki korelasi negatif paling tinggi adalah jasa pendidikan sebesar $-0,67$, sedangkan pertumbuhan ekonomi sektoral yang memiliki korelasi positif paling tinggi adalah Pengadaan Air, Pengelolaan Sampah, Limbah dan Daur Ulang yang mencapai 0,82 (lihat Tabel 8). Sementara itu, gambaran tingkat kemiskinan dari perspektif mikro menunjukkan bahwa status kemiskinan rumah tangga di Kota bandung pada tahun 2017 didominasi oleh kelompok rumah tangga yang berada golongan tidak miskin yang mencapai sebesar 85,03\%, disusul oleh Rentan Miskin (72\%), Hampir Miskin (27\%), Miskin (32\%) dan Sangat Miskin (22\%) (lihat Tabel 5). Penurunan kemiskinan di Kota Bandung sejauh ini masih dibayang-bayangi kemungkinan meningkatnya kelompok rumahtangga yang rentan miskin dan hampir miskin menjadi miskin bahkan sangat miskin yang disebabkan oleh peningkatan inflasi pada kelompok core disumbang oleh beberapa komoditas yang menjadi kebutuhan pada momen Idul Fitri dan fenomena mudik lebaran serta menjelang masuknya anak sekolah.

Tabel 5. Gambaran Status Kemiskinan Kota Bandung 2017

\begin{tabular}{lrrr}
\hline \multicolumn{1}{c}{$\begin{array}{c}\text { Status Miskin } \\
\text { Rumahtangga }\end{array}$} & Freq. & Percent & Cum. \\
\hline Tidak Miskin & 869 & 85.03 & 85.03 \\
Rentan Miskin & 72 & 7.05 & 92.07 \\
Hampir Miskin & 27 & 2,64 & 94.72 \\
Miskin & 32 & 3,13 & 97.85 \\
Sangat Miskin & 22 & 2,15 & 100 \\
\hline \multicolumn{1}{c}{ Total } & 1.022 & 100 & \\
\hline
\end{tabular}

Sumber : Susenas 2017, diolah 


\section{SIMPULAN DAN SARAN}

Relatif tingginya inflasi di Kota Bandung dibanding inflasi nasional dan Jawa Barat dapat membawa beban tersendiri bagi perekonomian masyarakat. Daya beli akan menurun ketika inflasi naik secara signifikan dan akan berdampak pada kesejahteraan masyarakat. Inflasi di Kota Bandung seringkali disebabkan harga komoditas pangan bergejolak atau disebut volatile food inflation. Sebagai daerah bukan penghasil komoditas pangan, maka harga komoditas bahan pangan di Kota Bandung sangat dipengaruhi oleh produksi dan distribusi dari daerah penghasil. Karakteristik yang sama juga terjadi di Kota besar di Jawa Barat lain seperti Kota Bogor dan Bekasi. Menjaga kelancaran dan ketersediaan pasokan bahan pangan marupakan hal yang mutlak dilakukan guna menjaga stabilitas inflasi yang bersumber dari gejolak harga bahan makanan. Operasi pasar yang selama ini dilakukan guna menjaga ketersediaan pasokan merupakan upaya kuratif dan belum cukup optimal jika tujuannya adalah menjaga stabilitas harga dalam jangka panjang. Hal tersebut disebabkan karena inflasi bersumber dari sisi pasokan (supply)

Sebagaimana diketahui, untuk memahami inflasi dari sisi supply, terutama untuk kelompok Bahan Makanan, pemahaman mengenai produksi dan distribusi bahan pangan menjadi penting. Hal ini mengingat karena adanya keterbatasan dari sisi produksi sementara jumlah permintaan terus meningkat sejalan dengan bertambahnya jumlah penduduk. Kegagalan memelihara cadangan pangan yang 
memadai - dalam arti masyarakat dapat memperoleh bahan makanan setiap saat dibutuhkan dan dengan harga terjangkau - dapat menimbulkan keresahan masyarakat dan ketidakstabilan, termasuk ketidakstabilan harga (fluktuasi harga). Oleh karenanya, diperlukan pemetaan tata niaga komoditas pangan eksisting untuk mengetahui pola perdagangan dan rantai pasoknya. Memang diperlukan sebuah kajian tersendiri untuk mengetahui secara persis tata niaga eksisting dari komoditas pangan. Namun, dengan diketahuinya tata niaga pangan, maka kebijakan yang dilakukan bukan hanya bersifat kuratif, namun juga dapat dilakukan secara struktural. Sebagai misal mengoptimalkan peran PD. Pasar untuk menjalankan fungsi food hubs, sebagaimana yang dijalankan oleh PT. Food Station Tjipinang Jaya, DKI Jakarta. Food hubs juga merupakan salah satu lembaga alternatif kelembagaan untuk mengatur keseimbangan pasokan produksi dan distribusi di suatu daerah. Menurut Matson (2013), food hubs berperan penting dalam memenuhi peningkatan permintaan konsumen atas produk makanan segar yang diproduksi secara lokal dan kurang tersedia di pasar tradisional serta mendorong terciptanya peluang pemasaran yang lebih luas dan memberi energi pada perekonomian lokal dan regional. Food Hubs juga merupakan suatu bisnis atau organisasi yang secara aktif mengelola agregasi, distribusi pemasaran produk pangan lokal yang teridentifikasi sumbernya (Barham et al., 2012). Tentunya, harus dilakukan pra-studi dalam pembentukan food hubs dalam rangka pengendalian harga bahan makanan di Kota Bandung. Dengan terjaganya laju inflasi di Kota Bandung melalui pengendalian harga bahan pangan, maka juga akan berdampak 
pada pengurangan angka kemiskinan. Hal tersebut disebabkan karena kemiskinan berkorelasi positif dengan laju inflasi dengan koefisien korelasi sebesar $0.82 \%$

Pertumbuhan Ekonomi Kota Bandung dengan data terakhir tahun 2017 menunjukkan penurunan menjadi $7.21 \%$ dibanding periode sebelumnya $7.69 \%$. Capaian pertumbuhan ekonomi tersebut juga merupakan yang terendah sejak tahun 2011. Faktor pelemahan ekonomi global patut diduga menjadi salah satu faktor penyebab penurunan pertumbuhan ekonomi, melalui dampaknya terhadap penurunan kinerja industri pengolahan yang didominasi oleh industri tekstil dan pakaian jadi, yang memiliki orientasi ekspor. Namun, tentu saja diperlukan kajian lebih mendalam untuk melihat faktor penurunan pertumbuhan ekonomi di Kota Bandung tersebut.

Kontributor sektoral terhadap PDRB Kota Bandung masih didominasi oleh sektor Perdagangan Besar, Eceran, Reparasi Mobil dan Sepeda Motor dan Industri Pengolahan. Namun demikian, kontribusi sektor industri pengolahan terhadap PDRB terus menurun. Hal ini menjadi indikasi bahwa aktivitas ekonomi mulai bergeser dari aktivitas sekunder ke aktivitas tersier. Hal tersebut juga dilihat dari peningkatan kontribusi sektor Transportasi dan Pergudangan serta sektor Informasi dan Komunikasi. Hal tersebut seyogyanya menjadi perhatian serius bagi Pemerintah Kota Bandung dalam upaya mengantisipasi dampak negatif dari adanya indikasi deindustrialisasi ini. Lebih dari itu, pertumbuhan ekonomi yang tercapai di Kota Bandung, juga terindikasi belum berkualitas, dimana terdapat 11 dari 17 sektor yang mana memiliki korelasi positif dengan tingkat kemiskinan. Secara umum, LPE Kota Bandung juga memiliki korelasi positif dengan tingkat 
kemiskinan. Artinya, pertumbuhan ekonomi yang ada memiliki kaitan positif dengan angka kemiskinan, dengan koefisien korelasi sebesar $0.44 \%$

Kemiskinan merupakan salah satu persoalan yang menjadi sorotan pemerintah Kota Bandung untuk ditanggulangi. Hal tersebut perlu dilakukan supaya pada tahun 2030 sesuai dengan tujuan poin pertama SDGs yaitu no poverty Kota Bandung dapat terbebas dari kemiskinan. Berdasarkan hasil estimasi menunjukkan bahwa tingginya pertumbuhan ekonomi di Kota bandung tidak berbanding lurus dengan penurunan tingkat kemiskinan. Hal ini menunjukkan bahwa kualitas pertumbuhan ekonomi di Kota Bandung ada permasalahan yang perlu diperhatikan. Oleh karena itu, Pemerintah Daerah dalam upaya mendorong pertumbuhan ekonomi harus tetap memperioritaskan pengurangan kemiskinan dan juga ketimpangan. Dengan demikian, jangan terjebak dengan pertumbuhan yang tinggi justru dapat tidak berbanding lurus dengan kesejahteraan masyarakat masyarakat. Selain itu, Pemerintah Daerah Kota Bandung dapat menyiapkan sejumlah langkah supaya penduduk rentan miskin ini tidak kembali menjadi miskin antara lain melalui pemberdayaan ekonomi rumah tangga. Oleh karena itulah, pemerintah fokus pada $40 \%$ penduduk kelompok ekonomi terendah. Kelompok inilah yang masuk ke dalam kategori sangat miskin, miskin, hampir miskin dan rentan miskin. Dengan demikian, kelompok inilah yang menjadi target utama program-program perlindungan sosial yang digulirkan pemerintah.

Pemberdayaan ekonomi terdiri atas dua hal yakni lapangan kerja dan kemudahan berusaha. Lapangan kerja sendiri harus diciptakan dan tidak cukup hanya dari anggaran pemerintah, namun juga harus dari investasi, terutama dari sisi 
sumberdaya manusia melalui pendidikan. Selain itu, adanya upaya dari pemerintah daerah untuk memberi kemudahan berusaha dengan cara memberikan akses pasar, kredit mikro dan juga kemitraan. Hal tersebut ditujukan agar usaha mikro kecil dan menengah (UMKM) dapat mandiri di masa datang.

\section{REFERENSI}

Badan Pusat Statistik. 2017. "Data dan Informasi Kemiskinan Kabupaten/Kota Tahun 2016”. Badan Pusat Statistik, Jakarta. . 2018. Perhitungan dan Analisis Kemiskinan Makro Indonesia Tahun 2018. Badan Pusat Statistik, Jakarta.

Badan Pusat Statistik Kota Bandung. 2018. Produk Domestik Regional Bruto Kota Bandung Menurut Lapangan Usaha. Badan Pusat Statistik Kota Bandung, Bandung.

Badan Pusat Statistik Kota Bandung. 2018. Kota Bandung Dalam Angka. Badan Pusat Statistik Kota Bandung, Bandung.

Badan Pusat Statistik Kota Bandung. 2019. Berita Resmi Statistik: Perkembangan Indeks Harga Konsumen. No. 01/01/32/Th. XXI, 02 Januari 2019

Badan Pusat Statistik Provinsi Jawa Barat. 2018. Produk Domestik Regional Bruto Provinsi Jawa Barat Menurut Lapangan Usaha. Badan Pusat Statistik Provinsi Jawa Barat, Bandung.

Bank Dunia. 2007. Era Baru Dalam Pengentasan Kemiskinan Di Indonesia. Bank Dunia, Jakarta.

Barham, J., Tropp, D., Enterline, K., Farbman, J., Fisk, J., \& Kiraly, S. (2012). Regional food hub resource guide. Washington, DC: US Department of Agriculture. Agricultural Marketing Service.

Berti, G., \& Mulligan, C. (2016). Competitiveness of small farms and innovative food supply chains: The role of food hubs in creating sustainable regional and local food systems. Sustainability, 8(7), 616.

Dariwardani. 2014. Analisis Dinamika Kemiskinan (Poverty Dynamics) di Bali Berdasarkan Data Susenas Panel 2008 - 2010. Jurnal Ekonomi Kuantitatif Terapan. Vol. 7 No. 1, Februari 2014. 
Haughton, Jonathan, dan Khandker, Shahidur R. 2012. "Pedoman Tentang Kemiskinan dan Ketimpangan (Handbook on Poverty and Inequality)". Salemba Empat, Jakarta.

Purwanto, E.A. 2007. Mengkaji Potensi Usaha Kecil dan Menengah (UKM) untuk Pembuatan Kebijakan Anti Kemiskinan di Indonesia. Jurnal Ilmu Sosial dan Ilmu Politik. ISSN 1,410-4946. Volume 10, Nomor 3, Maret 2007 (295324)

Sugandi, Y.S. 2018. Program Penanggulangan Kemiskinan Perkotaan: Pengalaman Kota Bandung Jurnal Analisis Kebijakan dan Pelayanan Publik. eISSN : 25276476 | pISSN : 25276476 